Check for updates

Cite this: J. Anal. At. Spectrom., 2021, 36,2704

Received 11th August 2021

Accepted 18th October 2021

DOI: 10.1039/d1ja00283j

rsc.li/jaas

\section{Applications of hydrogen as a collision and reaction cell gas for enhanced measurement capability applied to low level stable and radioactive isotope detection using ICP-MS/MS}

\author{
B. Russell, (D)*a S. L. Goddard, ${ }^{b}$ H. Mohamud, ${ }^{a}$ O. Pearson, ${ }^{a}$ Y. Zhang, ${ }^{c}$ H. Thompkins ${ }^{a}$ \\ and R. J. C. Brown (D) bd
}

\begin{abstract}
Tandem inductively coupled plasma mass spectrometry (ICP-MS/MS) with collision/reaction cell capability can achieve highly effective separation of spectral interferences. This improves confidence in measurement, reduces the detection limits achievable and expands the number of isotopes measurable in a range of industries, including semi-conductor, pharmaceutical, environmental, food and nuclear. Amongst the range of cell gases tested, hydrogen $\left(\mathrm{H}_{2}\right)$ has proven to be an effective cell gas, either used alone or in combination with other gases. This study demonstrates the benefits of using $\mathrm{H}_{2}$ in combination with ICP-MS/MS for improved detection of stable and radioactive pollutants of interest to a number of technical disciplines. This is presented through several case studies considering stable $\left({ }^{35} \mathrm{Cl}\right.$, ${ }^{40} \mathrm{Ca},{ }^{56} \mathrm{Fe}, \mathrm{Ni}$ isotopes) and radioactive $\left({ }^{36} \mathrm{Cl},{ }^{41} \mathrm{Ca},{ }^{63} \mathrm{Ni}\right.$ and $\left.{ }^{93} \mathrm{Mo}\right)$ isotopes in stable element standards and sample matrices including air quality filters and aqueous nuclear decommissioning waste.
\end{abstract}

\section{Introduction}

ICP-MS is a routine analytical technique for a range of sectors, capable of multi-element detection, measurement times of only several minutes per sample and detection limits in the $\mathrm{fg}^{-1}$ range. The flexibility of the instrument design means that measurement of gaseous, solid and, most frequently, aqueous samples is possible. In all cases, accurate measurement is dependent on the removal of several interferences. Firstly, isobaric overlap from an isotope of another element at a very similar mass to the analyte, which cannot be resolved by the detector. Secondly, polyatomic interferences formed by a combination of two or more isotopes in the high temperature plasma, with the product formed again having a very similar mass to the analyte. Finally, tailing is caused by an isotope at a significantly higher concentration one or two mass units either side of the analyte. Removal of these interferences is commonly achieved using chemical separation techniques such as solvent extraction, precipitation, ion exchange and/or extraction chromatography.

\footnotetext{
${ }^{a}$ Nuclear Metrology Group, National Physical Laboratory, Hampton Road, Teddington, UK. E-mail: ben.russell@npl.co.uk

${ }^{b}$ Air Quality and Aerosol Metrology Group, National Physical Laboratory, Hampton Road, Teddington, UK

'Electrochemistry Group, National Physical Laboratory, Hampton Road, Teddington, $U K$

${ }^{d}$ Department of Physics, University of Surrey, Guildford GU2 7XH, Surrey, UK
}

As ICP-MS has developed, instrument-based interference removal capability has improved, reducing or even removing the need for relatively time consuming offline chemical separation prior to measurement. One such option is using a collision and/or reaction gas in a pressurised cell for selective removal of isobaric and polyatomic interferences. Collisionreaction cells are a powerful tool for removal of spectral interferences in quadrupole ICP-MS instruments. A reaction gas is used to remove the analyte from known interferences. The likelihood of the reaction proceeding depends on the enthalpy of reaction between the gas and the elements involved. If the enthalpy of reaction is negative (exothermic), the reaction will occur spontaneously when the element and gas meet in the cell, whilst a positive enthalpy of reaction (endothermic) means energy is required and the reaction is less likely to proceed. ${ }^{1}$ The bond energies and ionisation energies of the reactants and products can be used to calculate the enthalpy of reaction.

A collision gas selectively removes polyatomic interferences based on their larger size compared to the analyte of the same mass. The gas will collide more frequently with polyatomic ions due to their larger collisional cross section, resulting in higher energy losses relative to the analyte. A bias voltage at the cell exit excludes these low kinetic energy polyatomics from entering the quadrupoles whilst the majority of the analyte signal is retained thus dramatically improving the detection limits achievable for the analytes of interest. The cell gas flow rate and bias voltage must be optimised for interference removal and analyte sensitivity for each application. ${ }^{1}$ 
The commercial availability of tandem mass spectrometry (ICP-MS/MS) has been proven to expand measurement capabilities in fields including semiconductor, pharmaceutical, environmental monitoring, and nuclear decommissioning. The additional quadrupole mass filter improves tailing removal compared to single quadrupole designs, as well as filtering the ion beam prior to the collision/reaction cell, simplifying understanding of the cell chemistry. ${ }^{1}$ The collision-reaction cell can accommodate a range of cell gases (e.g. $\mathrm{H}_{2}, \mathrm{O}_{2}, \mathrm{NH}_{3}, \mathrm{CH}_{4}$ and $\mathrm{CH}_{3} \mathrm{~F}$ ) to support or even replace relatively time-consuming offline chemical separation. ICP-MS/MS has expanded the number of isotopes measurable as well as reducing measurement uncertainty and the detection limits achievable for elements that suffer from significant interferences.

Hydrogen has been applied effectively as a cell gas for interference reduction. Eiden et al. proposed $\mathrm{H}_{2}$ as a method for selective removal of $\mathrm{Ar}$ and other plasma matrix ions, noting significant Ar suppression due to charge transfer from $\mathrm{Ar}^{+}$to form low $m / z$ ions $\mathrm{H}_{2}{ }^{+}$and $\mathrm{H}_{3}{ }^{+}{ }^{2}$ The same authors noted the suitability of $\mathrm{H}_{2}$ in efficiently reducing the Ar signal to enable measurement of analytes including ${ }^{40} \mathrm{Ca}$ and ${ }^{40} \mathrm{~K}\left({ }^{40} \mathrm{Ar}\right.$ isobar $)$, ${ }^{56} \mathrm{Fe}\left({ }^{40} \mathrm{Ar}^{16} \mathrm{O}\right.$ polyatomic $)$ and ${ }^{80} \mathrm{Se}\left({ }^{40} \mathrm{Ar}_{2}\right.$ dimer $) .{ }^{3}$ Several interference removal mechanisms have been proposed, including hydrogen atom transfer (eqn (1)), proton transfer (eqn (2)) and charge transfer (eqn (3)).,5 Table 1 gives some examples of elements that have benefitted from the use of $\mathrm{H}_{2}$ as a cell gas.

$$
\begin{aligned}
& \mathrm{Ar}^{+}+\mathrm{H}_{2} \rightarrow \mathrm{ArH}^{+}+\mathrm{H} \\
& \mathrm{ArH}^{+}+\mathrm{H}_{2} \rightarrow \mathrm{H}_{3}^{+}+\mathrm{Ar} \\
& \mathrm{Ar}^{+}+\mathrm{H}_{2} \rightarrow \mathrm{H}_{2}^{+}+\mathrm{Ar}
\end{aligned}
$$

If used as a collision gas, there is a lower analyte energy loss using $\mathrm{H}_{2}$ compared to heavier $\mathrm{He}$, improving sensitivity and potentially lowering the detection limits achievable. ${ }^{6}$ Hydrogen is known to work effectively for removal of argide based interferences, such as ${ }^{38} \mathrm{Ar}^{1} \mathrm{H}$ on ${ }^{39} \mathrm{~K},{ }^{40} \mathrm{Ar}^{12} \mathrm{C}$ on ${ }^{52} \mathrm{Cr}$ and ${ }^{40} \mathrm{Ar}^{40} \mathrm{Ar}$ on ${ }^{80} \mathrm{Se} .{ }^{5,7}$ In one example, ${ }^{40} \mathrm{Ar}$ plasma gas was suppressed via a charge transfer reaction with $\mathrm{H}_{2}$ for measurement of ${ }^{40} \mathrm{Ca}$ impurities in ultrapure water. ${ }^{8}$ This was supported by operating under cold plasma conditions (RF reduced to approximately $600 \mathrm{~W}$ compared to approximately $1300 \mathrm{~W}$ ) to reduce the $\mathrm{Ar}$ signal due to its high ionisation energy, with the background equivalent concentration (BEC) calculated $\left(0.041 \mathrm{pg} \mathrm{g}^{-1}\right)$ as being two orders of magnitude lower than single quadrupole ICP-MS. Hydrogen has also been used as a reaction gas to measure ${ }^{31} \mathrm{P}$ in the presence of high ${ }^{30} \mathrm{Si}$ concentrations in $\mathrm{Si}$ wafers. The ${ }^{31} \mathrm{P}$ signal was shifted to ${ }^{31} \mathrm{P}^{1} \mathrm{H}_{4}$ whilst polyatomic ${ }^{30} \mathrm{Si}^{1} \mathrm{H}$ remained on mass. ${ }^{9,10}$

Hydrogen has also been effectively used in combination with other reaction cell gases. In the case of improved interference removal for measurement of Ti nanoparticles, $\mathrm{H}_{2}$ was used in combination with $\mathrm{O}_{2}$ to measure $\mathrm{Ti}$ as ${ }^{48} \mathrm{Ti}^{16} \mathrm{O}$. The addition of $\mathrm{H}_{2}$ effectively shifted polyatomic ${ }^{48} \mathrm{Ca}^{16} \mathrm{O}$ to ${ }^{48} \mathrm{Ca}^{16} \mathrm{O}^{1} \mathrm{H}$, whilst Ti remains as ${ }^{48} \mathrm{Ti}^{16} \mathrm{O}$. This is beneficial to a number of applications including paints, cosmetics and pharmaceuticals. ${ }^{\mathbf{1 1}}$ The same combination of gases was also used for measurement of trace Se in Ni alloys. High concentrations of Se can lead to weakness in alloy composition, which is particularly significant in industrial applications where high temperature resistance is required e.g. turbine blades in aircraft. Argon-based interferences on Se isotopes (e.g. ${ }^{40} \mathrm{Ar}^{36} \mathrm{Ar}$ on ${ }^{76} \mathrm{Se}$ and ${ }^{40} \mathrm{Ar}^{38} \mathrm{Ar}$ on ${ }^{78} \mathrm{Se}$ ) can be removed using $\mathrm{H}_{2}$, whilst Ni matrix interferences (e.g. ${ }^{60} \mathrm{Ni}^{16} \mathrm{O}$ on ${ }^{76} \mathrm{Se}$ and ${ }^{62} \mathrm{Ni}^{16} \mathrm{O}$ on ${ }^{78} \mathrm{Se}$ ) can be removed using $\mathrm{O}_{2}$ to convert Se to SeO. ${ }^{12}$ The use of tandem ICP-MS/MS also removes water adducts that would otherwise enter the cell and lead to potential interferences such as ${ }^{60} \mathrm{Ni}^{16} \mathrm{O}\left(\mathrm{H}_{2} \mathrm{O}\right){ }^{+}$on ${ }^{78} \mathrm{Se}^{16} \mathrm{O}$. As an example, ${ }^{78} \mathrm{Se}$ instrument detection limits of $12.9 \mathrm{ng} \mathrm{\textrm {L } ^ { - 1 }}$ and

\begin{tabular}{|c|c|c|c|c|c|c|}
\hline Ultrapure water & ${ }^{40} \mathrm{Ca}$ & ${ }^{40} \mathrm{Ar}$ & ${ }^{40} \mathrm{Ca}$ & Acidified water & 0.041 (BEC) & 16 \\
\hline Titanium nanoparticles & ${ }^{48} \mathrm{Ti}$ & ${ }^{48} \mathrm{Ca}$ & $\begin{array}{l}{ }^{48} \mathrm{Ti}^{16} \mathrm{O} \\
{ }^{48} \mathrm{Ca}^{16} \mathrm{O}^{1} \mathrm{H}\end{array}$ & Dilution and sonication & $\begin{array}{l}\sim 30 \mathrm{~nm} \text { particle } \\
\text { size }\end{array}$ & 11 \\
\hline$N$-Methyl-2-pyrrolidone & ${ }^{28} \mathrm{Si}^{35} \mathrm{Cl}$ & ${ }^{14} \mathrm{~N}_{2},{ }^{12} \mathrm{C}^{16} \mathrm{O}^{16} \mathrm{O}^{18} \mathrm{OH}$ & ${ }^{28} \mathrm{Si}^{35} \mathrm{ClH}_{2}$ & Distillation and acidification & $\begin{array}{l}15800(\mathrm{BEC}) \\
34200(\mathrm{BEC})\end{array}$ & 10 \\
\hline $\begin{array}{l}\text { CRMs (leaves, pine } \\
\text { needles, rice flour) }\end{array}$ & ${ }^{111} \mathrm{Cd}$ & ${ }^{95} \mathrm{Mo}^{16} \mathrm{O}$ & ${ }^{111} \mathrm{Cd}$ & Microwave digestion and dilution & - & 11 \\
\hline
\end{tabular}
$18.8 \mathrm{ng} \mathrm{L}^{-1}$ were achieved in $\mathrm{H}_{2}$ and $\mathrm{O}_{2}$ modes, respectively.

Table 1 Examples of applications using $\mathrm{H}_{2}$ as a cell gas stainless

steel, aqueous waste 
Iglesias et al. investigated multiple cell gases for removal of Ar-based interferences affecting measurement of Fe and Se. ${ }^{13}$ In both cases, a mixture of $\mathrm{H}_{2}$ and He returned the lowest detection limits, with values of $2 \mathrm{ng} \mathrm{\textrm {L } ^ { - 1 }}$ and $6 \mathrm{ng} \mathrm{L}^{-1}$ for ${ }^{80} \mathrm{Se}$ and ${ }^{56} \mathrm{Fe}$, respectively. A mixture of gases was also used for separation of the long-lived radionuclide ${ }^{93} \mathrm{Zr}$ from stable isobar ${ }^{93} \mathrm{Nb}^{.14,15}$ Specifically, $\mathrm{H}_{2}$ was combined with $\mathrm{NH}_{3}$ to shift ${ }^{93} \mathrm{Zr}$ to ${ }^{93} \mathrm{Zr}\left(\mathrm{NH}_{3}\right)_{6}$, with no increase in background from ${ }^{93} \mathrm{Nb}\left(\mathrm{NH}_{3}\right)_{6}$ at mass fractions up to $5 \times 10^{4} \mathrm{pg} \mathrm{g}^{-1}$, which was higher than the levels present in the stainless steel and aqueous waste samples measured. The presence of $\mathrm{H}_{2}$ increased the efficiency of cell product formation compared to using $\mathrm{NH}_{3}$ alone. Detection limits of $1.1 \mathrm{pg} \mathrm{g}^{-1}$ and $8.6 \mathrm{pg} \mathrm{g}^{-1}$ were calculated for steel and aqueous waste samples, respectively, which was several orders of magnitude below the regulatory limits.

This study demonstrates the combination of ICP-MS/MS with $\mathrm{H}_{2}$ for expanding the range of applicable measurement capabilities. Methods have been developed by the Air Quality and Aerosol Metrology, and Nuclear Metrology Groups at the National Physical Laboratory (NPL) for measurement of stable and radioactive isotopes. Several case studies are presented including for the measurement of new elements and improved sensitivity and detection limits when using $\mathrm{H}_{2}$ alone or in combination with other cell gases.

The focus for stable isotopes is the measurement of air quality filter samples, with the aim to develop methods with improved interference removal to (i) improve analyte sensitivity and detection limits, and (ii) enable isotope ratio measurement to aid source apportionment, focusing on $\mathrm{Fe}$ and Ni isotopes. NPL is the UK's National Metrology Institute and the current operator of the UK Metals Monitoring Network (hereafter referred to as 'the Metals Network') on behalf of the Environment Agency and the UK governmental Department for Environment, Food and Rural Affairs (Defra). ${ }^{18}$ The Metals Network consists of monitoring sites all around the UK that sample airborne particulate matter with an aerodynamic diameter less than $10 \mu \mathrm{m}$ (PM10) onto filters. These filters are prepared for analysis by microwave acid digestion and analysed by ICP-MS for a suite of twelve metals. ${ }^{19}$ Results are reported to the EU to assess UK compliance with air quality legislation. ${ }^{20,21}$ For the current study, improvements to the determination of ${ }^{56} \mathrm{Fe}$ were attempted. The development of a method to accurately measure all stable $\mathrm{Ni}$ isotopes was also investigated.

The focus for radioactive isotopes was to investigate radionuclides that must be accurately characterised in nuclear wastes and environmental samples to ensure the correct waste sentencing route, contributing to safe and cost-effective decommissioning and ensuring safety to the workforce and the public. ICP-MS/MS has proven a valuable part of the radioanalytical toolbox for rapid measurement of radionuclides including ${ }^{90} \mathrm{Sr},{ }^{93} \mathrm{Zr},{ }^{129} \mathrm{I},{ }^{135} \mathrm{Cs} /{ }^{137} \mathrm{Cs}$ and ${ }^{236} \mathrm{U} /{ }^{238} \mathrm{U} \cdot{ }^{14,15,22-25} \mathrm{This}$ study focuses on radionuclides that suffer from multiple spectral interferences that may benefit from the interference removal capabilities offered by ICP-MS/MS: ${ }^{36} \mathrm{Cl},{ }^{41} \mathrm{Ca},{ }^{63} \mathrm{Ni}$ and ${ }^{93}$ Mo.

\section{Experimental}

\subsection{Reagents and materials}

Stable element standards (100-1000 $\mu \mathrm{g} \mathrm{g}^{-1}$, Fluka Analytical) were used for initial instrument tuning. For $\mathrm{Cl}$, calibration standards were prepared from gravimetric dilution of hydrochloric acid (Fisher Scientific, Trace Analysis Grade). Single radionuclide standards were provided by the NPL Nuclear Metrology Group and diluted to the required activity concentrations in a dedicated radioactive source preparation facility. All standards were prepared in nitric acid (Fisher Scientific, Trace Analysis Grade) diluted to $2 \%(\mathrm{v} / \mathrm{v})$ in deionised water obtained using an ELGA purelab flex water purification system (ELGA, Veolia Water, Marlow, UK, $18 \mathrm{M} \Omega \mathrm{cm}, 5 \mathrm{ppb}$ Total Organic Carbon).

Iron-56 was measured in a set of five calibration standards (with an approximate range of 1-10 $\mathrm{ng} \mathrm{g}^{-1}$ ) and a matrixmatched acid blank $\left(1 \% \mathrm{HNO}_{3}\right)$. The following isotopes were measured in a calibration standard containing $5 \mathrm{ng} \mathrm{g}^{-1} \mathrm{Fe}, \mathrm{Ni}$, $\mathrm{Cu}, \mathrm{Zn}$ and a matrix-matched acid blank $\left(1 \% \mathrm{HNO}_{3}\right):{ }^{57} \mathrm{Fe},{ }^{58} \mathrm{Ni}$, ${ }^{60} \mathrm{Ni},{ }^{63} \mathrm{Cu},{ }^{64} \mathrm{Ni}$ and ${ }^{66} \mathrm{Zn}$.

Nickel-63 was measured in aqueous waste samples provided by Sellafield Ltd. Stable ${ }^{40} \mathrm{Ca}$ and radioactive ${ }^{41} \mathrm{Ca}$ was measured in several different concrete samples: inactive blank concrete prepared at NPL, bio-shield concrete obtained from SCK-CEN (Belgium), and ${ }^{41} \mathrm{Ca}$-spiked concrete from a European Metrology Research Programme project 'Metrology for Radioactive Waste Management' (MetroRWM). ${ }^{26}$ Additionally, ${ }^{41} \mathrm{Ca} /{ }^{40} \mathrm{Ca}$ standard solutions (ERM-AE701) supplied by the Institute of Reference Materials and Measurements (IRMM) (Geel, Belgium) were measured, with ${ }^{41} \mathrm{Ca} /{ }^{40} \mathrm{Ca}$ ratios ranging from $10^{-6}$ to $10^{-13}$.

\subsection{Instrumentation}

Experimental work was carried out using an Agilent 8800 and Agilent 8900 ICP-MS/MS. Compared to the Agilent 8800, the newer generation 8900 benefits from an upgraded collision/ reaction cell and the capability to apply an axial acceleration voltage to the octopole rods in the reaction cell. This increases the transmission rate and sensitivity for product ions. This is especially useful when analyte ions lose energy due to collisions/reactions with cell gases, as the product ions can be re-accelerated and sensitivity regained, potentially improving sensitivity and detection limits.

The instruments are both equipped with two quadrupole mass filters ( $Q 1$ and $Q 2)$ separated by a collision-reaction cell and fitted with a quartz double-pass spray chamber, MicroMist nebuliser (Glass Expansion) and the X-lens setup. The 8800 utilised nickel sample and skimmer cones; the 8900 was fitted with platinum tipped cones (Crawford Scientific). Four cell gas lines were fitted to each instrument, connected between the supply and the instrument by approximately $1 \mathrm{~m}$ of $2.1 \mathrm{~mm}$ internal diameter stainless steel tubing: dedicated hydrogen and helium lines, a corrosive gas line $\left(10 \% \mathrm{NH}_{3}\right.$ balanced in $90 \% \mathrm{He})$ and a non-corrosive line $\left(\mathrm{O}_{2}\right)$. All cell gases and $\mathrm{Ar}$ plasma gas were provided by BOC with a purity of N6.0. 
Hydrogen was supplied to both instruments from a Linde NM Plus generator. To reduce the risk of high water and $\mathrm{O}_{2}$ content from the use of a generator, an Agilent Gas Clean Filter was fitted between the supply and the instrument.

The instruments were conditioned with the cell gases of interest overnight prior to use to ensure the gas lines were fully purged. The instrument was tuned daily in Single Quadrupole mode (only Q2 operating) using a $1 \mathrm{ng} \mathrm{mL}^{-1}$ standard solution consisting of $\mathrm{Be}, \mathrm{Y}, \mathrm{Ce}$ and $\mathrm{Tl}$ in $2 \%(\mathrm{v} / \mathrm{v}) \mathrm{HNO}_{3}$. The sensitivity and repeatability were assessed at low $\left({ }^{9} \mathrm{Be}\right)$, medium $\left({ }^{89} \mathrm{Y}\right)$ and high $\left({ }^{205} \mathrm{Tl}\right)$ mass, whilst the $\mathrm{CeO}$ and doubly charged $\mathrm{Ce}$ formation was measured as the 156/140 and 70/140 ratio. Each monitored element had to reach a threshold sensitivity with an uncertainty $<5 \%$, and oxide and doubly charged formation had to be less than $2 \%$. The 8900 instrument was conditioned and tuned in the same way, with the exception that the $1 \mathrm{ng} \mathrm{mL}^{-1}$ standard solution contained ${ }^{7} \mathrm{Li}$ for low mass tuning.

\subsection{Methodology}

For all applications, the ramp cell gas function was used to give an indication of the optimal gas flow rate with regards to interference removal and analyte sensitivity. When using $\mathrm{NH}_{3}$ as a reaction gas, the product ion scan function was used to assess potential cell products. In this setting, $Q 1$ is set to a single mass and $Q 2$ scans the entire mass range. This setup simplifies understanding of the cell chemistry and facilitates the identification of the various $\mathrm{NH}$-based products that can form. For both the ramp cell gas and the product ion scan, the instrument background was first assessed using blank samples, with any cases of elevated background discussed in Section 3.

For all studies, the instrument background, analyte sensitivity, (BEC) and detection limit (LOD) were considered. The BEC is the instrument blank response expressed as a concentration, calculated by dividing the counts per second (CPS) in the blank by the sensitivity determined from a calibration curve. The BEC is monitored as part of the ramp cell gas function described above, highlighting the change in sensitivity and the blank as a function of cell gas flow rate. The LOD is calculated as the equivalent concentration of three times the standard deviation of the instrument blank.

For all applications, initial testing was carried out using single element standards, followed by mixed standards of the analyte and potential interferences. After daily tuning, the impact of operating in Single Quad and MS/MS mode (both Q1 and Q2 operating) on analyte sensitivity and interference removal was investigated, as was the impact of different collision and reaction cell gases. The instrument was operated in custom tune mode, enabling users to modify conditions, focusing in this study on the cell gas flow rate, as well as the cell energy discrimination and octopole bias voltages.

For radionuclide applications, the optimised method was validated where possible using real samples. Aqueous nuclear waste samples were measured as received, focusing on detection of ${ }^{63} \mathrm{Ni}$. Calcium-41 was measured in concrete samples following borate fusion dissolution and multi-stage radiochemical separation. ${ }^{27}$ In the absence of an active tracer ${ }^{95} \mathrm{Mo}$ was investigated as a stable analogue of ${ }^{93} \mathrm{Mo}$.

\section{Results and discussion}

\subsection{Impact of $\mathbf{H}_{2}$ on analyte sensitivity and instrument background}

An increase in $\mathrm{H}_{2}$ flow rate reduced the instrument background, shown for several masses in Fig. 1. In agreement with previous studies (eqn (1)-(3) and Table 1), $\mathrm{H}_{2}$ was effective in reducing the ${ }^{40} \mathrm{Ar}$ background at $m / z=40$, with the signal dropping by a factor of $2 \times 10^{5}$ from $7.3 \times 10^{7} \mathrm{CPS}$ at $1 \mathrm{~mL} \mathrm{~min}^{-1}$ to $400 \mathrm{CPS}$

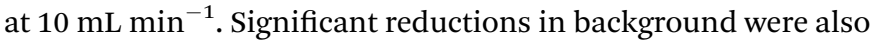
observed at $m / z=29\left({ }^{28} \mathrm{Si}^{1} \mathrm{H}\right.$ and $\left.{ }^{28} \mathrm{Si}\right)$ by a factor of $4 \times 10^{5}$ to $<5$ CPS at $10 \mathrm{~mL} \min ^{-1}$ over the same flow rate range. At $m / z=37$ $\left({ }^{37} \mathrm{Cl}\right)$, the signal was reduced from $7.4 \times 10^{5} \mathrm{CPS}$ to $<5 \mathrm{CPS}$.

A multi-element standard solution was run at $\mathrm{H}_{2}$ flow rates from 1-10 $\mathrm{mL} \mathrm{min}^{-1}$ at $1 \mathrm{~mL}$ increments to assess the impact of flow rate on sensitivity. Fig. 2 and 3 shows the impact of collisional focusing, where an increase in $\mathrm{H}_{2}$ flow rate can focus the analyte ions closer to the centre of the beam, improving sensitivity. As the flow rate increases beyond the optimal level, scattering of the ion beam reduces the sensitivity. As the analyte mass increases, the optimum flow rate for collisional focusing also increases. This is because heavier ions are already closer to the centre of the beam than lighter ions and can tolerate higher cell gas flow rates. For example, the highest sensitivity for ${ }^{24} \mathrm{Mg}$ is recorded at a $\mathrm{H}_{2}$ flow rate of $2 \mathrm{~mL} \mathrm{~min}^{-1}$, increasing to 6 $\mathrm{mL} \min ^{-1}$ for ${ }^{175} \mathrm{Lu}$ and $8 \mathrm{~mL} \min ^{-1}$ for ${ }^{238} \mathrm{U}$. The results highlight the importance of custom tuning the cell gas flow rate for each analyte.

The remainder of this section focuses on several case studies (Table 2) where $\mathrm{H}_{2}$ has been effectively used alone or in combination with another reaction gas to reduce the impact of spectral interferences.

\subsection{Case studies}

3.2.1. Chlorine isotopes. Stable ${ }^{35} \mathrm{Cl}$ has been successfully measured by ICP-MS/MS. ${ }^{28,29}$ The main interference of concern is polyatomic ${ }^{16} \mathrm{O}^{18} \mathrm{O}^{1} \mathrm{H}$, which can be overcome using a sequential reaction with $\mathrm{H}_{2}$ to shift ${ }^{35} \mathrm{Cl}$ to ${ }^{35} \mathrm{Cl}^{1} \mathrm{H}$ and then to

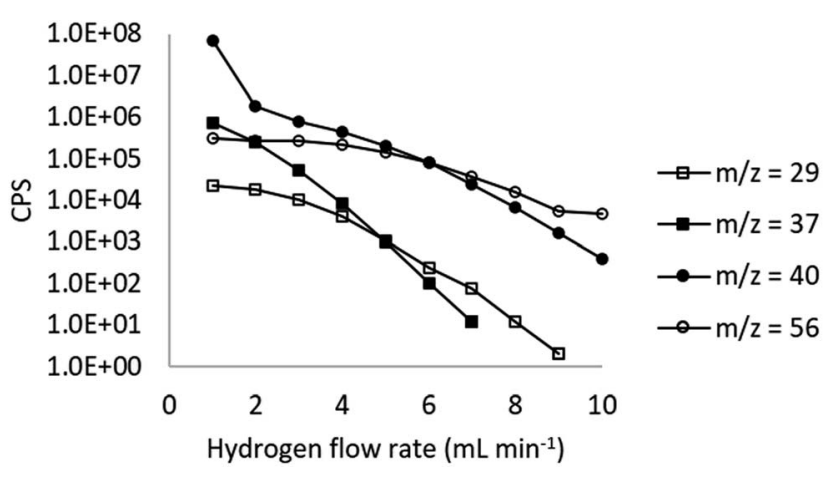

Fig. 1 Impact of $\mathrm{H}_{2}$ flow rate on instrument background (data shown for Agilent 8800). 


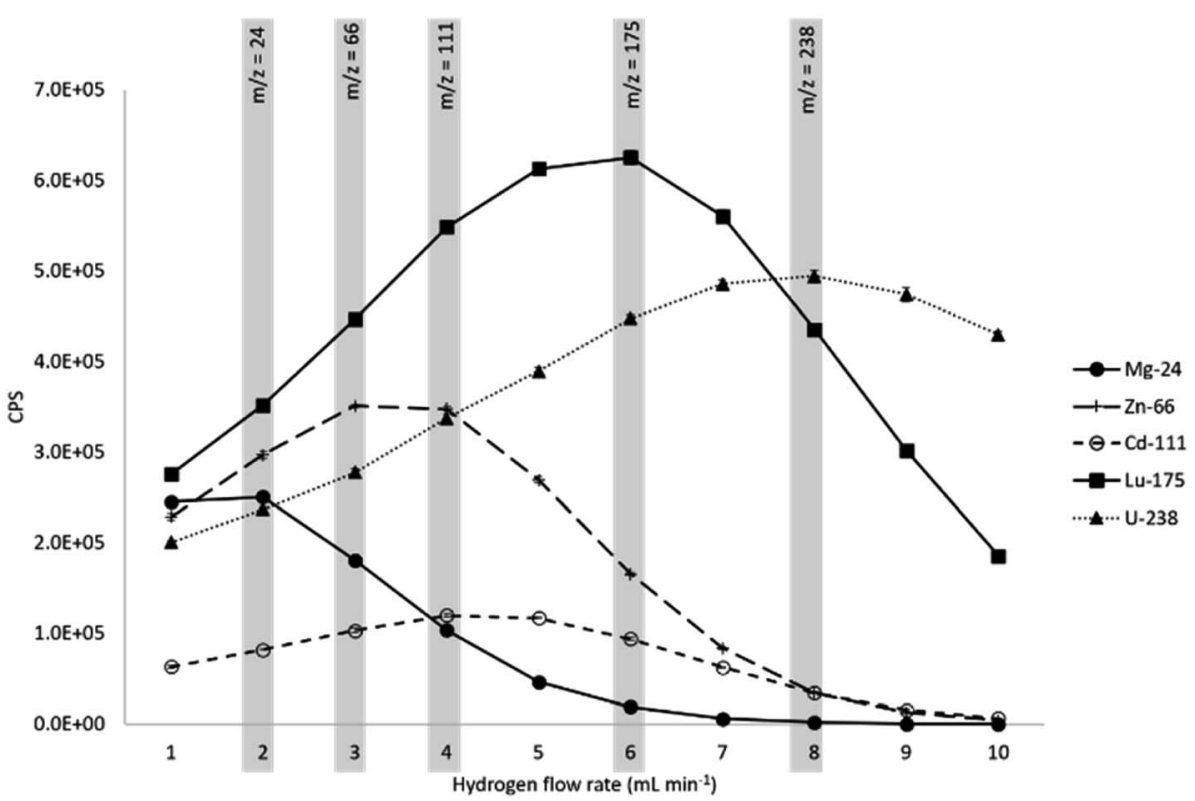

Fig. 2 Impact of $\mathrm{H}_{2}$ flow rate on analyte sensitivity. Grey bars show the $\mathrm{H}_{2}$ flow rate corresponding to peak sensitivity at different mass-to-charge ratios $(\mathrm{m} / \mathrm{z})$.

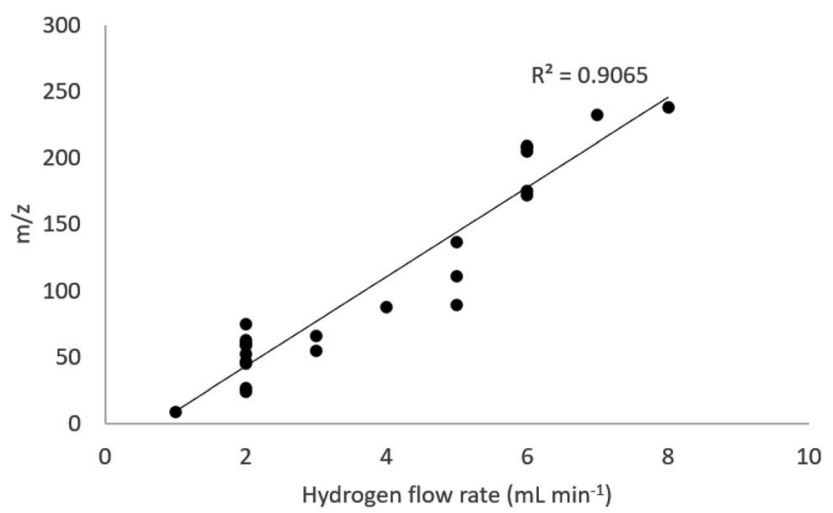

Fig. 3 Correlation between hydrogen flow rate at peak sensitivity and mass-to-charge $(\mathrm{m} / \mathrm{z})$ ratio.

${ }^{35} \mathrm{Cl}^{1} \mathrm{H}_{2}$, whilst the reaction with ${ }^{16} \mathrm{O}^{18} \mathrm{O}^{1} \mathrm{H}$ does not proceed. The high first ionisation energy of $\mathrm{Cl}(12.97 \mathrm{eV})$ and resulting low sensitivity must be considered, as should the presence of $\mathrm{Cl}$ as an impurity in reagents if low detection limits are required. In deionised water, a detection limit of $0.28 \mathrm{ng} \mathrm{g}^{-1}$ was achieved using an Agilent $8900 .^{28}$ In a separate study, the same instrument setup was used for measurement in crude oil, with a detection limit of $0.01 \mu \mathrm{g} \mathrm{g}^{-1}$ calculated. ${ }^{29}$

The sequential reaction with $\mathrm{H}_{2}$ was applied to the measurement of ${ }^{35} \mathrm{Cl}$ as the formation of ${ }^{35} \mathrm{Cl}^{1} \mathrm{H}_{2}$ to assist with a project assessing the corrosion susceptibility of $304 \mathrm{~L}$ SS materials with a novel coating intended to be applied on fuel racks that are used to store Advanced Gas-Cooled Reactor (AGR) fuel under an $\mathrm{NaOH}(\mathrm{pH} 11.4)$ pond solution. The storage environment is commonly controlled in alkaline conditions with caustic dosing to maintain $\mathrm{pH}$ at 11.4. However, transient changes in local chemical/electrochemical environment is not uncommon to observe, such as increase in chlorides, decrease in $\mathrm{pH}$ and increase in oxidation potentials due to radiolysis. Therefore, it is important to measurement traceable chloride concentrations in the $\mu \mathrm{g} \mathrm{g}^{-1}$ to $\mathrm{ng} \mathrm{g}^{-1}$ concentration range in the test environment to correlate with the corrosion resistance of coated 304L SS in aqueous solution.

Table 2 Summary of results from selected case studies that benefit from use of $\mathrm{H}_{2}$ cell gas

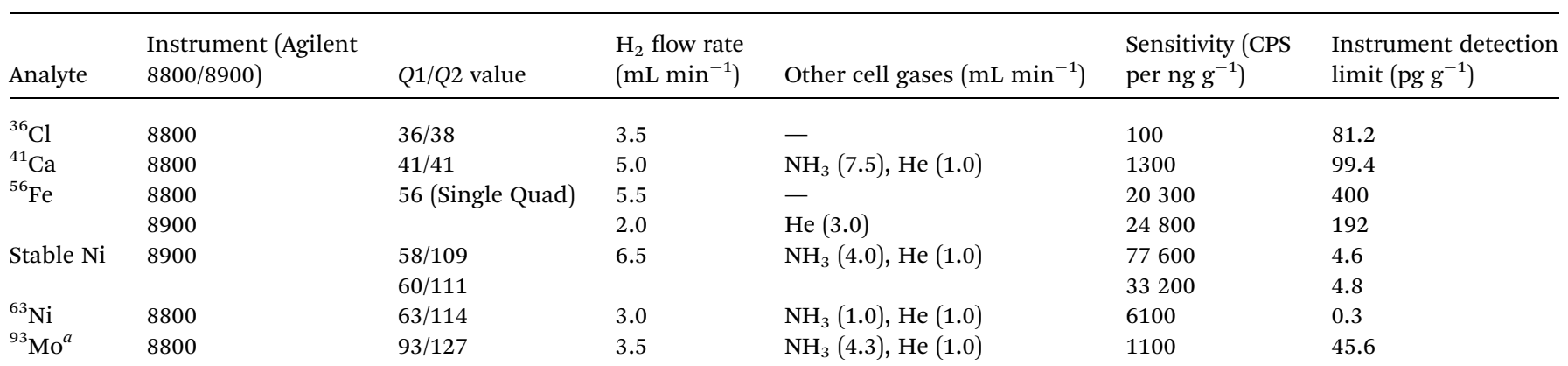

${ }^{a}$ Sensitivity and limit of detection calculated from stable analogues. 
Samples were measured as received in dilute $\mathrm{NaOH}$ solution. The instrument was first conditioned with deionised water for one hour, followed by a $\mathrm{NaOH}$ blank solution for one hour. The optimal $\mathrm{H}_{2}$ gas flow rate was determined to be $3.5 \mathrm{~mL} \mathrm{~min}{ }^{-1}$. Initial tests show the blank level to vary between runs, with the lowest values achieved after cleaning the sample introduction system and interface cones. A sensitivity of around 100 CPS was achieved for a $1 \mathrm{ng} \mathrm{g}^{-1}$ standard, which is approximately three orders of magnitude lower than the majority of other elements under the same conditions, due to the high first ionisation energy of Cl. Despite the low sensitivity, it was possible to quantify $\mathrm{Cl}$ in all samples, with the results showing good agreement with those measured in parallel using ion chromatography.

The results for stable $\mathrm{Cl}$ highlighted the potential for measurement of radioactive ${ }^{36} \mathrm{Cl}$, not previously measured by ICP-MS. It is a long-lived radionuclide (half-life $3.02(4) \times 10^{5}$ years) and is formed by neutron activation of stable ${ }^{35} \mathrm{Cl}$, which is present as an impurity in concrete and other reactor components. $^{\text {30,31 }}$ Chlorine-36 can be measured by liquid scintillation counting (LSC), with detection limits on the order of 10-15 $\mathrm{mBq} \mathrm{g}^{-1}$ achievable, equivalent to $8.2-12.3 \mathrm{pg} \mathrm{g}^{-1} \cdot{ }^{32}$ The long half-life makes ${ }^{36} \mathrm{Cl}$ theoretically suitable for ICP-MS measurement, with a higher sample throughput compared to decay counting techniques.

The same sequential $\mathrm{H}_{2}$ shift was applied, with $Q 1$ and $Q 2$ set to $m / z=36$ and 38 , respectively. Using this approach, isobaric interferences from ${ }^{36} \mathrm{~S}$ (36.0\% abundance) and ${ }^{36} \mathrm{Ar}$ from the plasma gas (0.3\% abundance) do not form ${ }^{36} \mathrm{~S}^{1} \mathrm{H}_{2}$ or ${ }^{36} \mathrm{Ar}^{1} \mathrm{H}_{2}$ and are therefore minimised, as is polyatomic ${ }^{35} \mathrm{Cl}^{1} \mathrm{H}$, which is not expected to form ${ }^{35} \mathrm{Cl}^{1} \mathrm{H}_{3}$. There was no increase in background up to stable $\mathrm{Cl}$ concentrations of $80 \mu \mathrm{g} \mathrm{g}^{-1}$. The optimal $\mathrm{H}_{2}$ flow rate for ${ }^{36} \mathrm{Cl}$ was determined to be $4.5-5.0 \mathrm{~mL} \mathrm{~min}^{-1}$, with an instrument background of $<20$ CPS, a sensitivity of approximately $2300 \mathrm{CPS}$ for a $9.9 \mathrm{~Bq} \mathrm{~g}^{-1}\left(8.1 \times 10^{3} \mathrm{pg} \mathrm{g}^{-1}\right){ }^{36} \mathrm{Cl}$ standard and a calculated detection limit of $81.2 \mathrm{pg} \mathrm{\textrm {g } ^ { - 1 }}$ (equivalent to $98.8 \mathrm{mBq} \mathrm{\textrm {g } ^ { - 1 }}$ ). Future work will focus on measurement of decommissioning samples containing ${ }^{36} \mathrm{Cl}$.

3.2.2. Calcium-41. Calcium- 41 is formed by neutron activation of stable ${ }^{40} \mathrm{Ca}$ (96.94\% abundance), a major component of concrete used in reactor shielding and construction materials. The significant amount of concrete at nuclear facilities makes ${ }^{41} \mathrm{Ca}$ a key radionuclide for characterisation of low and intermediate level waste, as well as for long-term waste monitoring. Rapid and reliable characterisation procedures for measuring ${ }^{41} \mathrm{Ca}$ in concrete samples will contribute to accurate and safe classification of waste. The long half-life of ${ }^{41} \mathrm{Ca}\left(1.002(17) \times 10^{5}\right.$ years $)$ is theoretically suitable to ICP-MS detection, however, this has previously been prevented by isobaric $\left({ }^{41} \mathrm{~K}\right)$, polyatomic $\left({ }^{40} \mathrm{Ca}^{1} \mathrm{H}\right.$ and $\left.{ }^{40} \mathrm{Ar}^{1} \mathrm{H}\right)$ and tailing $\left({ }^{40} \mathrm{Ar}\right.$ and $\left.{ }^{40} \mathrm{Ca}\right)$ interferences. As a result, alternative mass spectrometric techniques (accelerator (AMS) and resonance ionisation (RIMS) mass spectrometry) $)^{33,34}$ and liquid scintillation counting (LSC) $)^{35,36}$ have been effectively used, with detection limits in the $0.003 \mathrm{fg} \mathrm{g}^{-1}\left(1 \times 10^{-8} \mathrm{~Bq} \mathrm{~g}^{-1}\right)$ range and ${ }^{41} \mathrm{Ca} /{ }^{40} \mathrm{Ca}$ ratios detectable down to $10^{-13}$ detectable. ${ }^{37,38}$

Following on from the successful detection of ${ }^{40} \mathrm{Ca}$ by ICPMS/MS in several studies, it was recently proven that the interference removal capabilities made ${ }^{41} \mathrm{Ca}$ detection feasible at ${ }^{41} \mathrm{Ca} /{ }^{40} \mathrm{Ca}$ ratios of $10^{-6}$ and $10^{-7}$, with an instrument detection limit of $0.1 \mathrm{ng} \mathrm{g}^{-1}\left(0.3 \mathrm{~Bq} \mathrm{~g}^{-1}\right) .{ }^{27}$ The addition of $\mathrm{H}_{2}$ to the cell improved the suppression of ${ }^{40} \mathrm{Ar}^{1} \mathrm{H}$ and ${ }^{40} \mathrm{Ar}$ interferences compared to using $\mathrm{NH}_{3}$ alone, or indeed compared to any other single or mixed cell gas combination. Using an Agilent 8800 at the optimised flow rates of $7.5 \mathrm{~mL} \mathrm{~min}^{-1}$ and 5.0 $\mathrm{mL} \min ^{-1}$ for $\mathrm{NH}_{3}$ and $\mathrm{H}_{2}$, respectively, the background at $\mathrm{m} / \mathrm{z}$ $=41$ was reduced to $<10 \mathrm{CPS}$, compared to $\sim 2.5 \times 10^{9} \mathrm{CPS}$ at 0.5 $\mathrm{mL} \min ^{-1} \mathrm{NH}_{3}$. This gas flow rate had the highest signal-tonoise ratio of any of the gas flow rates tested $\left(1.7 \times 10^{5}\right)$, with a sensitivity of $1300 \mathrm{CPS}$ for a $1 \mathrm{ng} \mathrm{g}^{-1}$ solution based on stable ${ }^{40} \mathrm{Ca}$ standards.

One limitation of this study was the low sensitivity preventing measurement below ${ }^{41} \mathrm{Ca} /{ }^{40} \mathrm{Ca}$ ratios of $10^{-7}$, which will be required for decommissioning samples and can be achieved by LSC, AMS and RIMS. Stable Ca standards were run on an Agilent 8900 over the same range of cell gas conditions to see if ICP-MS/ MS capability for ${ }^{41} \mathrm{Ca}$ could be improved. At $\mathrm{NH}_{3}$ and $\mathrm{H}_{2}$ flow rates of $7.5 \mathrm{~mL} \min ^{-1}$ and $5.0 \mathrm{~mL} \min ^{-1}$, respectively, the sensitivity was 9700 CPS for a $1 \mathrm{ng} \mathrm{g}^{-1}$ solution, which was 7.5 times higher than that achieved for the 8800. As was observed with Fe (Section 3.2.3), the instrument background was also higher when using the newer generation 8900 instrument. However, the optimal signal to noise ratio achieved using the 8900 was $9.0 \times 10^{5}$, compared to $1.7 \times 10^{5}$ for the 8800 . Whilst this improvement will not bring ICP-MS/MS in line with AMS, RIMS and LSC capability, it does demonstrate the improvements made with the latest generation instruments, and that detection of challenging radionuclides such as ${ }^{41} \mathrm{Ca}$ is now feasible.

3.2.3. Iron-56. Iron is measured in samples for a multitude of applications. For ICP-MS, the main analytical concern is the plasma-based polyatomic interference, ${ }^{40} \mathrm{Ar}^{16} \mathrm{O}$, on the most abundant Fe isotope, ${ }^{56} \mathrm{Fe}$ (91.8\% abundance) ${ }^{39}$ Helium mode is the conventional collision gas used address this interference. ${ }^{40,41}$ Other researchers have used $\mathrm{H}_{2},{ }^{42}$ or $\mathrm{CH}_{4}$ as a reaction gas. ${ }^{43}$ Dufailly et al., (2006) reported using a combination of He and $\mathrm{H}_{2}$ for iron determination in foodstuffs. ${ }^{44}$ Iglesias et al. (2002) trialled various gas combinations, with the lowest detection limit observed using $\mathrm{He}$ and $\mathrm{H}_{2} \cdot{ }^{13}$

Of the twelve metals analysed by NPL for the Metals Network, the detection limits for Fe are the highest, even with the use of $\mathrm{He}$ as a collision gas to reduce the ${ }^{40} \mathrm{Ar}^{16} \mathrm{O}$ signal at $m / z 56$. In this study, $\mathrm{H}_{2}$ was investigated as an alternative and results compared from the 8800 and 8900 instruments. The joint aims were to (i) find a method to improve analyte sensitivity and detection limits for air quality samples and (ii) assess the sensitivity improvements offered by the 8900 .

Iron-56 was measured on-mass in Single Quad mode. Helium and $\mathrm{H}_{2}$ were compared for their effectiveness as collision gases to remove polyatomic ${ }^{40} \mathrm{Ar}^{16} \mathrm{O}$. Operating in $\mathrm{MS} / \mathrm{MS}$ mode did not offer any improved interference removal, as the ${ }^{40} \mathrm{Ar}^{16} \mathrm{O}$ interference is formed in the plasma before $Q 1$. These measurements were performed on both the 8800 and 8900 instruments.

The ramp cell gas determined the optimal $\mathrm{He}$ and $\mathrm{H}_{2}$ flow rates for the 8800 instrument to be $5 \mathrm{~mL} \min ^{-1}$ and 5.5 
$\mathrm{mL} \min ^{-1}$, respectively (Table 3 ). For the 8900 instrument, the optimised flow rates were slightly higher at $5.5 \mathrm{~mL} \mathrm{~min}^{-1}$ for He and $6.5 \mathrm{~mL} \mathrm{~min}^{-1}$ for $\mathrm{H}_{2}$.

Table 3 shows that the use of $\mathrm{H}_{2}$ as the collision gas results in a more sensitive method for Fe determination compared to He. The sensitivity was higher by a factor of two with the 8800 (10 500 CPS per $\mathrm{ng} \mathrm{g}^{-1}$ for He, compared to 20300 CPS with $\mathrm{H}_{2}$ ), and a factor of three with the 8900 (9300 CPS per $\mathrm{ng} \mathrm{g}^{-1}$ with He, compared to 31400 CPS with $\mathrm{H}_{2}$ ). The detection limits and background equivalents were also lower with $\mathrm{H}_{2}$. In terms of comparing the two ICP-MS instruments, the 8800 and 8900 provided comparable results for Fe when He was used as the collision gas. When $\mathrm{H}_{2}$ was used the sensitivity was 1.5 times higher with the 8900; however, a lower background equivalent $\left(0.36 \mathrm{ng} \mathrm{g}^{-1}\right)$ and detection limit $\left(0.40 \mathrm{ng} \mathrm{g}^{-1}\right)$ was achieved with the 8800 . It seems that the improved sensitivity of the 8900 extends below the detection limit to the background signal.

Following on from a study by Iglesias et al., ${ }^{13}$ a combination of $\mathrm{H}_{2}$ and $\mathrm{He}$ was also investigated. For the 8800 instrument, the detection limit was not improved compared to using $\mathrm{H}_{2}$ alone. However, for the 8900 , a detection limit of $0.19 \mathrm{ng} \mathrm{g}^{-1}$ was calculated at the optimised $\mathrm{H}_{2}$ and He flow rates of 2.0 and 3.0 $\mathrm{mL} \min ^{-1}$, respectively (Table 3 ). This is an improvement over the $0.56 \mathrm{ng} \mathrm{g}^{-1}$ calculated using $\mathrm{H}_{2}$ only.

Using the 8900, the combination of $\mathrm{H}_{2}$ and $\mathrm{He}$ resulted in a lower Fe sensitivity compared to $\mathrm{H}_{2}$ alone (24 800 CPS per ng $\mathrm{g}^{-1}$ compared to $\left.31400 \mathrm{CPS}\right)$. However, the difference in count rate for the different acid blanks used was significant using $\mathrm{H}_{2}$ (16 $300 \mathrm{CPS}$ ) compared to $\mathrm{H}_{2}$ and $\mathrm{He}$ (3920 CPS).

This study highlighted the importance of closely controlling the cleanliness of reagents used. An acid blank count rate of $14600 \mathrm{CPS}$ at $\mathrm{m} / \mathrm{z}=56$ was recorded on the 8800 when an online internal standard solution containing indium was connected via a mixing block. This was reduced to 7400 CPS without the internal standard solution. It was concluded that preparation of reagents must be carefully controlled when measuring $\mathrm{Fe}$, as in this case the internal standard solution prepared was contaminated with significant levels of $\mathrm{Fe}$, so could not be used. Further consideration should also be given to the long-term variation in background at $m / z=56$, as changes in the Ar plasma gas flow rate, cell gas flow rate or other background ion contributions could all contribute to variations in the signal.

3.2.4. Nickel isotopes. Nickel is a significant metal of interest in relation to the Metals Network. Measured ambient concentrations at a number of the monitoring sites exceed the target value (20 $\mathrm{ng} \mathrm{m}^{-3}$ ) or assessment threshold values (10 and $14 \mathrm{ng} \mathrm{m}^{-3}$ for the lower and upper assessment thresholds, respectively) specified in the Fourth Air Quality Daughter Directive (DD) $\left(2004 / 107 / \mathrm{EC}^{20}\right)$ in any given year. Industrial facilities including a nickel refinery and a producer of nickelbased alloys in the local vicinities of the affected monitoring sites are thought to be the sources of the nickel emissions. ${ }^{19}$ In some cases, there are multiple industrial facilities that could influence nickel concentrations at a single monitoring site, and it has also been suggested that some of the nickel could come from re-suspension of dust from historical local sources.

The ICP-MS method for Metals Network samples measures ${ }^{60} \mathrm{Ni}$ (26.2\% abundance) to avoid the isobaric interference from ${ }^{58} \mathrm{Fe}$ on the most abundant $\mathrm{Ni}$ isotope at $\mathrm{m} / \mathrm{z}=58(68.1 \%$ abundance). However, the capability to make accurate measurements of all $\mathrm{Ni}$ isotopes to enable isotope ratio analysis could provide useful data for source apportionment in this context. The challenge is to overcome isobaric interferences from $\mathrm{Fe}$ and $\mathrm{Zn}$ at $m / z=58$ and 64 , respectively (Table 4). There could also be tailing interferences from ${ }^{63} \mathrm{Cu}$ and ${ }^{65} \mathrm{Cu}$ on the neighbouring nickel isotopes ${ }^{62} \mathrm{Ni}\left(3.6 \%\right.$ abundance) and ${ }^{64} \mathrm{Ni}$ (0.9\% abundance). ${ }^{39}$

Product ion scans were performed on the 8900 instrument to investigate reaction-cell separation of ${ }^{57} \mathrm{Fe},{ }^{58} \mathrm{Ni},{ }^{60} \mathrm{Ni},{ }^{63} \mathrm{Cu},{ }^{64} \mathrm{Ni}$ and ${ }^{66} \mathrm{Zn}$. The first method used $\mathrm{NH}_{3}$ as the cell gas to facilitate a mass shift, whilst the second method utilised a combination of $\mathrm{H}_{2}$ and $\mathrm{NH}_{3}$ cell gases. The reaction of $\mathrm{NH}_{3}$ with several analytes including $\mathrm{Ni}$ has been noted previously, ${ }^{45}$ leading to trace level determination not being advised. However, online interference removal opens the possibility of isotopic ratio measurements without the need for relatively time-consuming offline separation.

Using only $\mathrm{NH}_{3}$ cell gas at a flow rate of $3 \mathrm{~mL} \mathrm{~min}^{-1}$, the product ion scan results showed formation of several cell products that could potentially be used to separate Ni from interferences $(m / z+17,+34$ and +51$)$. Of these, $m / z+51$ was the most promising, equivalent to $\mathrm{Ni}\left(\mathrm{NH}_{3}\right)_{3}$. The sensitivity for the signal at $m / z+51$ for $\mathrm{Ni}$ was equivalent to $17 \%$ of the total signal, compared to $1 \%$ for $\mathrm{Fe}$ and $<1 \%$ for $\mathrm{Cu}$ and $\mathrm{Zn}$. A mass shift of $m / z+17\left(\mathrm{NH}_{3}\right)$ was not considered suitable; the signal for $\mathrm{Ni}$ was equivalent to just $2 \%$ of the total signal, $\mathrm{Zn}$ was $6 \%$, $\mathrm{Cu} 2 \%$ and $\mathrm{Fe}$ was $1 \%$. A mass shift of $\mathrm{m} / z+34\left(\mathrm{NH}_{3}\right)_{2}$ provided different but still undesirable results, with the Ni signal equivalent to $11 \%$ of the total, and $28 \%, 19 \%$, and $3 \%$ for $\mathrm{Cu}, \mathrm{Fe}$ and $\mathrm{Zn}$, respectively. For all cell products, the trends for these four elements agreed with data from the instrument manufacturer,

Table 3 Calibration data for ${ }^{56} \mathrm{Fe}$ with $\mathrm{He}$ or $\mathrm{H}_{2}$ as the collision gas on Agilent 8800 and 8900 instruments

\begin{tabular}{|c|c|c|c|c|c|c|}
\hline Cell gas flow rate $\left(\mathrm{mL} \mathrm{min}{ }^{-1}\right)$ & $5.0(\mathrm{He})$ & $5.5\left(\mathrm{H}_{2}\right)$ & $5.5(\mathrm{He})$ & $6.5\left(\mathrm{H}_{2}\right)$ & $\begin{array}{l}1.5\left(\mathrm{H}_{2}\right) \\
3.0(\mathrm{He})\end{array}$ & $\begin{array}{l}2.0\left(\mathrm{H}_{2}\right) \\
3.0(\mathrm{He})\end{array}$ \\
\hline Average acid blank (CPS) & 9600 & 7400 & 9300 & 16300 & 9360 & 3920 \\
\hline Background equivalent (BEC: $n \mathrm{~g}^{-1}$ ) & 0.93 & 0.36 & 1.02 & 0.53 & 0.52 & 0.16 \\
\hline Detection limit (LOD) $\left(\mathrm{ng} \mathrm{g}^{-1}\right)$ & 1.00 & 0.40 & 1.20 & 0.56 & 0.91 & 0.19 \\
\hline
\end{tabular}


Table 4 Nickel isotopes and Fe, Co, Zn and Cu-based interferences

\begin{tabular}{llll}
\hline $\begin{array}{l}\text { Ni isotope (\% Isobaric } \\
\text { abundance) }\end{array}$ & interference & $\begin{array}{l}\text { Polyatomic } \\
\text { interference }\end{array}$ & $\begin{array}{l}\text { Tailing } \\
\text { interference }\end{array}$ \\
\hline${ }^{58} \mathrm{Ni}(68.1)$ & ${ }^{58} \mathrm{Fe}$ & ${ }^{57} \mathrm{Fe}^{1} \mathrm{H}$ & ${ }^{59} \mathrm{Co}$ \\
${ }^{60} \mathrm{Ni}(26.2)$ & - & ${ }^{59} \mathrm{Co}^{1} \mathrm{H}$ & ${ }^{59} \mathrm{Co}$ \\
${ }^{61} \mathrm{Ni}(1.1)$ & - & ${ }^{60} \mathrm{Ni}^{1} \mathrm{H}$ & ${ }^{60} \mathrm{Ni}$ \\
${ }^{62} \mathrm{Ni}(3.6)$ & - & ${ }^{61} \mathrm{Ni}^{1} \mathrm{H}$ & ${ }^{63} \mathrm{Cu}$ \\
${ }^{64} \mathrm{Ni}(0.9)$ & ${ }^{64} \mathrm{Zn}$ & ${ }^{63} \mathrm{Cu}^{1} \mathrm{H}$ & ${ }^{63} \mathrm{Cu},{ }^{65} \mathrm{Cu}$
\end{tabular}

which also did not detect any other cell products other than $\mathrm{m} / \mathrm{z}$ $+17,+34$ and +51 . $^{1}$

The addition of $\mathrm{H}_{2}$ along with $\mathrm{NH}_{3}$ enhanced the formation of $\mathrm{Ni}\left(\mathrm{NH}_{3}\right)_{3}$, whilst having a limited impact on the same mass shifts for Fe, $\mathrm{Cu}$ and $\mathrm{Zn}$ (Fig. 4). The optimised $\mathrm{NH}_{3}$ and $\mathrm{H}_{2}$ flow

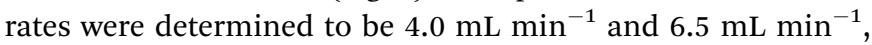
respectively. Of the total signals, for both ${ }^{60} \mathrm{Ni}$ and ${ }^{58} \mathrm{Ni} /{ }^{58} \mathrm{Fe}$ (onmass and mass shift channels $+17,+34,+51), 51 \%$ was observed on the $m / z+51$ channel, compared to $37 \%$ remaining on-mass. The ${ }^{57} \mathrm{Fe}\left(\mathrm{NH}_{3}\right)_{3}$ response at $m / z+51$ remains significantly lower than on-mass, just $3.2 \%$ of the total compared to $56 \%$ on-mass and $40 \%$ at $m / z+34$. Combined with the fact that the isotopic abundance of ${ }^{58} \mathrm{Fe}$ is only $0.28 \%$, it can be assumed that the response at $m / z=109$ is attributable to $\mathrm{Ni}\left(\mathrm{NH}_{3}\right)_{3}$. The responses for ${ }^{63} \mathrm{Cu}\left(\mathrm{NH}_{3}\right)_{3}$ and ${ }^{64} \mathrm{Zn}\left(\mathrm{NH}_{3}\right)_{3}$ ions also remain below on-mass levels. The response for ${ }^{64} \mathrm{Zn} / \mathrm{Ni}$ at $m / z+51$ is also much less than on-mass $(3.3 \%$ of total signal at $m / z+51$, compared to $80 \%$ on-mass), despite the presence of the $\mathrm{Ni}$ isotope. However, the natural abundance of ${ }^{64} \mathrm{Ni}$ is only $0.9 \%$, so would be lost amid any shifted signal from ${ }^{64} \mathrm{Zn}$ (48.6\% natural abundance).

A further Ramp Cell Gas optimisation using $\mathrm{H}_{2}$ with $\mathrm{NH}_{3}$ was performed on the 8800 . As with the 8900 , it was observed that for all elements, an increase in $\mathrm{H}_{2}$ flow rate increases the formation of $\left(\mathrm{NH}_{3}\right)_{3}$ cell products compared to $\mathrm{NH}_{3}$ alone, and the formation of $\mathrm{Ni}\left(\mathrm{NH}_{3}\right)_{3}$ is favoured over the products of $\mathrm{Fe}$, $\mathrm{Cu}$ and $\mathrm{Zn}$.
At optimised $\mathrm{NH}_{3}$ and $\mathrm{H}_{2}$ flow rates of $2 \mathrm{~mL} \mathrm{~min}^{-1}$ and 2.5 $\mathrm{mL} \min ^{-1}$ respectively, the $\mathrm{Ni}\left(\mathrm{NH}_{3}\right)_{3}$ signal was equivalent to $77.7 \%$ of the signal measured on-mass (based on ${ }^{58} \mathrm{Ni}$ ). This compares to $7.5 \%$ for ${ }^{57} \mathrm{Fe}, 0.9 \%$ for ${ }^{63} \mathrm{Cu}$ and $2.9 \%$ for ${ }^{64} \mathrm{Zn}$, suggesting cell-based separation is possible. As the $\mathrm{H}_{2}$ flow rate increased above $2.5 \mathrm{~mL} \mathrm{~min}{ }^{-1}$, the $\mathrm{Ni}\left(\mathrm{NH}_{3}\right)_{3}$ signal decreased, whilst the signals for $\mathrm{Fe}\left(\mathrm{NH}_{3}\right)_{3}, \mathrm{Cu}\left(\mathrm{NH}_{3}\right)_{3}$ and $\mathrm{Zn}\left(\mathrm{NH}_{3}\right)_{3}$ increased until flow rates of 5.0, 3.5 and $6.5 \mathrm{~mL} \mathrm{~min}^{-1}$, respectively.

The optimised $\mathrm{NH}_{3}$ and $\mathrm{H}_{2}$ flow rates differed significantly between the 8800 ( $2 \mathrm{~mL} \mathrm{~min}^{-1}$ and $2.5 \mathrm{~mL} \mathrm{~min}^{-1}$ respectively) and 8900 ( $4.0 \mathrm{~mL} \mathrm{~min}^{-1}$ and $6.5 \mathrm{~mL} \mathrm{~min}^{-1}$ respectively). This is likely due to the increased sensitivity of the 8900 allowing for greater tolerance of higher flow rates without adversely affecting sensitivity. Additionally, the optimisation of the 8900 gas flow rates focussed on the ${ }^{60} \mathrm{Ni}$ signal, so fine tuning to minimise the signals for the other elements could also explain the optimised flow rate discrepancy.

The effective combination of $\mathrm{NH}_{3}$ and $\mathrm{H}_{2}$ is auspicious for the development of an interference-free method for the determination of the majority of Ni isotopes. It is hoped that this method will prove suitable for isotope ratio analysis of air quality filter samples, as well as for other applications such as improved understanding of the early formation of the solar system and as a geochemical tracer in magmatic processes. ${ }^{\mathbf{4 6 , 4 7}}$ It must be considered that more complex sample matrices may result in additional and higher concentrations of interferences that would likely require modification of the instrument setup presented in this study.

The same cell gas combination was successfully used for detection of radioactive ${ }^{63} \mathrm{Ni}$ (half-life $98.70(24)$ years), formed by neutron activation of stable ${ }^{62} \mathrm{Ni}$ and a radionuclide of significant interest in nuclear waste characterisation and decommissioning. The formation of ${ }^{63} \mathrm{Ni}\left(\mathrm{NH}_{3}\right)_{3}$ provided cellbased separation from isobaric ${ }^{63} \mathrm{Cu}$ and polyatomic ${ }^{62} \mathrm{Ni}^{1} \mathrm{H}$, whilst MS/MS mode effectively removed ${ }^{62} \mathrm{Ni}$ tailing. A product ion scan using $\mathrm{NH}_{3}$ gas at a flow rate of $3 \mathrm{~mL} \mathrm{~min}^{-1}$ was initially tested using stable ${ }^{58} \mathrm{Ni}$ and ${ }^{63} \mathrm{Cu}$. The ${ }^{58} \mathrm{Ni}\left(\mathrm{NH}_{3}\right)_{3} /{ }^{63} \mathrm{Cu}\left(\mathrm{NH}_{3}\right)_{3}$

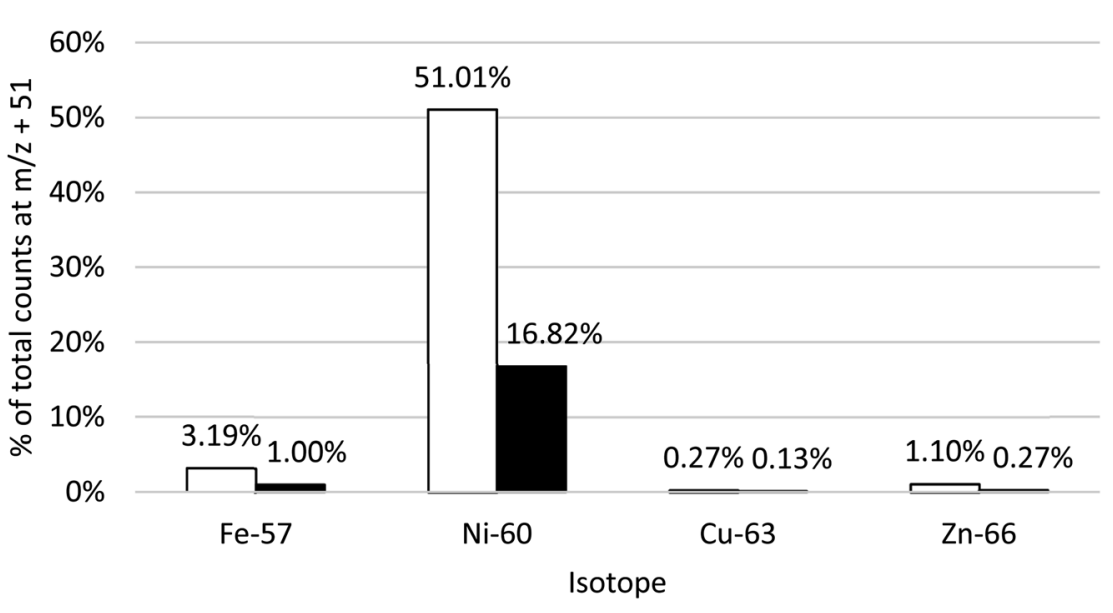

$\square$ Ammonia and hydrogen $\quad$ Ammonia only

Fig. 4 Responses of ${ }^{57} \mathrm{Fe},{ }^{60} \mathrm{Ni},{ }^{63} \mathrm{Cu}$ and ${ }^{66} \mathrm{Zn}$ using $\mathrm{NH}_{3}$ only and $\mathrm{H}_{2}$ and $\mathrm{NH}_{3}$ cell gases to facilitate a mass shift of $m / z+51\left(\mathrm{NH}_{3}\right)_{3}$. 
formation rate was 35.4 based on the difference in CPS for each isotope, which increased at lower gas flow rates at the expense of ${ }^{58} \mathrm{Ni}\left(\mathrm{NH}_{3}\right)_{3}$ sensitivity, which was $>99 \%$ lower at $0.5 \mathrm{~mL} \mathrm{~min}{ }^{-1}$ compared to $3 \mathrm{~mL} \mathrm{~min}{ }^{-1}$. Compared to $\mathrm{NH}_{3}$ alone, the addition of $\mathrm{H}_{2}$ gas increased $\mathrm{Ni}\left(\mathrm{NH}_{3}\right)_{3}$ formation up to a flow rate of 1.5 $\mathrm{mL} \mathrm{min}^{-1}$, with a comparatively low increase in $\mathrm{Cu}\left(\mathrm{NH}_{3}\right)_{3}$. The ${ }^{58} \mathrm{Ni}\left(\mathrm{NH}_{3}\right)_{3} /{ }^{63} \mathrm{Cu}\left(\mathrm{NH}_{3}\right)_{3}$ formation rate increased to around 100 at $1 \mathrm{~mL} \mathrm{~min}{ }^{-1} \mathrm{NH}_{3}$ and $3 \mathrm{~mL} \mathrm{~min}{ }^{-1} \mathrm{H}_{2}$, with a sensitivity of $61000 \mathrm{CPS}$ for a $10 \mathrm{ng} \mathrm{g}^{-1} \mathrm{Ni}$ solution. This compares to a similar separation factor of $\sim 90$ at $1 \mathrm{~mL} \mathrm{~min}{ }^{-1} \mathrm{NH}_{3}$ without $\mathrm{H}_{2}$, but with a low Ni sensitivity of 145 CPS for a $10 \mathrm{ng} \mathrm{g} \mathrm{g}^{-1}$ solution.

The optimised cell conditions were tested on ${ }^{63} \mathrm{Ni}$ standards, with an instrument detection limit of $0.25 \mathrm{pg} \mathrm{g}^{-1}\left(0.52 \mathrm{~Bq} \mathrm{~g}^{-1}\right)$, with the background at $m / z=63$ of $<10 \mathrm{CPS}$, compared to $\sim 500$ CPS in no-gas mode. When tested on aqueous waste samples without chemical separation, the method detection limit was calculated as $12.1 \mathrm{pg} \mathrm{g}^{-1}\left(25.6 \mathrm{~Bq} \mathrm{~g}^{-1}\right)$ due to the elevated ${ }^{63} \mathrm{Cu}$ concentrations. This could be improved by offline chemical separation such as ion exchange or extraction chromatography. ${ }^{4-50}$ However, this demonstrates that direct measurement of ${ }^{63} \mathrm{Ni}$ in real samples is feasible.

The relatively short half-life of ${ }^{63} \mathrm{Ni}$ means the detection limits achievable by ICP-MS/MS are higher than those of liquid scintillation counting. However, the measurement time of ICPMS/MS of several minutes per sample offers an improved sample throughput, which is further improved by cell based separation reducing the reliance on relatively time consuming offline separation. This also reduces the analyst working time and the amount of secondary waste generated through the use of separation reagents and materials.

The Agilent 8900 used in this study was not able to run radioactive materials. However, the higher sensitivity compared to the 8900 achieved using stable Ni standards could potentially improve the detection limits achievable. Future work will look at the potential of ICP-MS/MS for measurement of longer-lived ${ }^{59} \mathrm{Ni}$ (half-life $76(5) \times 10^{3}$ years), which would have an additional advantage of ${ }^{59} \mathrm{Ni} /{ }^{63} \mathrm{Ni}$ ratio measurements for source attribution. Accurate measurement requires effective removal of isobaric ${ }^{59} \mathrm{Co}$ (100\% abundance), which was not achieved using the $\mathrm{NH}_{3}+\mathrm{H}_{2}$ method presented in this study, as well as polyatomic ${ }^{58} \mathrm{Ni}^{1} \mathrm{H}$ and ${ }^{58} \mathrm{Ni}$ tailing interferences.

3.2.5. Molybdenum-93. Molybdenum-93 is an important radionuclide to measure accurately during the decommissioning of nuclear sites, as well as for monitoring of stored and disposed wastes. Molybdenum-93 has weak gamma emissions but is measurable by LSC. Molybdenum-93 has a half-life of $4.0(8) \times 10^{3}$ years, and is therefore potentially measurable by ICP-MS. In order to achieve accurate measurement, isobaric interferences from stable ${ }^{93} \mathrm{Nb}$ (100\% abundance) and radioactive ${ }^{93} \mathrm{Zr}$ (half-life $1.61(6) \times 10^{6}$ years) must be overcome, as well as tailing from ${ }^{92} \mathrm{Mo},{ }^{92} \mathrm{Zr}$, ${ }^{94} \mathrm{Mo}$ and ${ }^{94} \mathrm{Zr}$, and polyatomic ${ }^{92} \mathrm{Zr}^{1} \mathrm{H}$ and ${ }^{92} \mathrm{Mo}^{1} \mathrm{H}$. Additionally, the relatively short half-life for ICP-MS represents a challenge with regards to sensitivity, with an activity concentration of $1 \mathrm{~Bq} \mathrm{~g}^{-1}$ equivalent to $28.1 \mathrm{pg} \mathrm{g}^{-1}$.

The starting point for this work was the successful use of $\mathrm{NH}_{3}+\mathrm{H}_{2}$ for measurement of ${ }^{93} \mathrm{Zr}$ as ${ }^{93} \mathrm{Zr}\left(\mathrm{NH}_{3}\right)_{6}$ in previous studies. ${ }^{\mathbf{1 4 , 1 5}}$ In these studies, interference removal of ${ }^{93}$ Mo was the focus, rather than measurement of this radionuclide. Stable ${ }^{90} \mathrm{Zr},{ }^{93} \mathrm{Nb}$ and ${ }^{95} \mathrm{Mo}$ were run through product ion scans with Q1 set to 90, 93 and 95, respectively, using only $\mathrm{NH}_{3}$ at a flow rate of $3 \mathrm{~mL} \mathrm{~min}^{-1}$. The results identified a mass shift of 34 (equivalent to $\left(\mathrm{NH}_{3}\right)_{2}$ ) as potentially offering separation of Mo from $\mathrm{Zr}$ and $\mathrm{Nb}$. The majority of the Mo signal (85.22\%) stayed on mass, compared to approximately $2 \%$ for $\mathrm{Zr}$ and $\mathrm{Nb}$, which produced a range of product ions (Fig. 5). At a mass shift of $\mathrm{m} / \mathrm{z}$ $+34,12 \%$ of the total Mo signal was detected, compared to $<0.1 \%$ for $\mathrm{Zr}$ and $\mathrm{Nb}$. There were no other significant cell products ( $>1 \%$ of the total signal) detected for Mo.

The $\mathrm{NH}_{3}$ ramp cell gas result suggested that the peak $\mathrm{Mo}\left(\mathrm{NH}_{3}\right)_{2}$ sensitivity was achieved at a flow rate of 4.0-4.5 $\mathrm{mL} \min ^{-1}$, with no significant change in instrument background from $\mathrm{Zr}\left(\mathrm{NH}_{3}\right)_{2}$ or $\mathrm{Nb}\left(\mathrm{NH}_{3}\right)_{2}$ over all $\mathrm{NH}_{3}$ flow rates. At a fixed $\mathrm{NH}_{3}$ flow rate of $4.3 \mathrm{~mL} \mathrm{~min}{ }^{-1}$, the cell gas ramp was repeated for varied $\mathrm{H}_{2}$ flow rates. This had no impact on the $\mathrm{Nb}\left(\mathrm{NH}_{3}\right)_{2}$ or $\mathrm{Zr}\left(\mathrm{NH}_{3}\right)_{2}$ signal, however, the signal for $\mathrm{Mo}\left(\mathrm{NH}_{3}\right)_{2}$

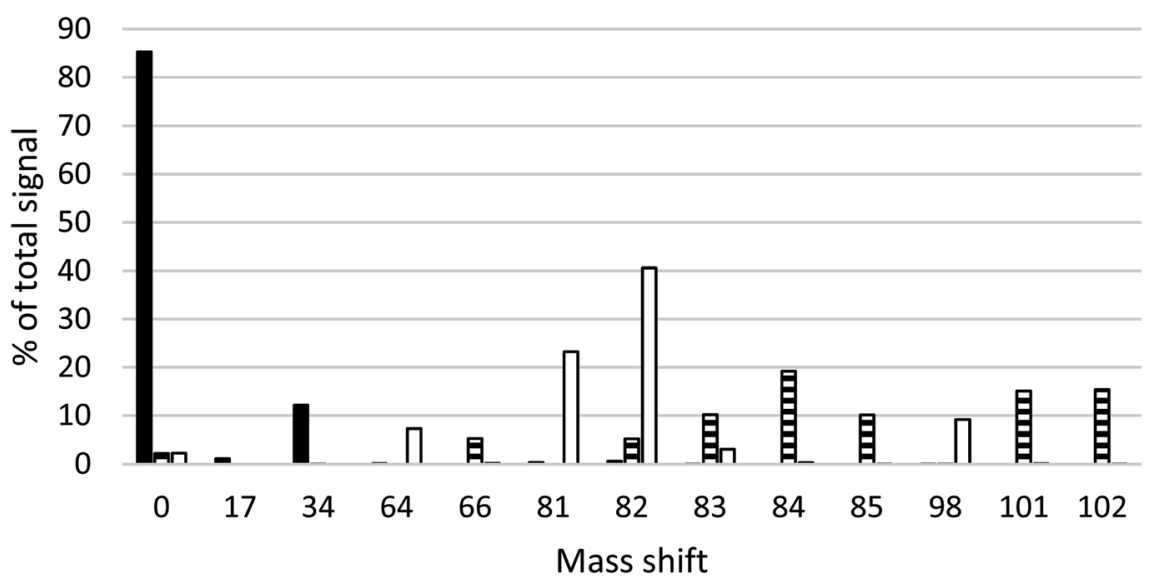

Molybdenum EZirconium $\square$ Niobium

Fig. 5 Results of product ion scan for Mo, Zr and $\mathrm{Nb}$. 
increased by approximately $10 \%$ compared to using $\mathrm{NH}_{3}$ alone. The optimal $\mathrm{H}_{2}$ flow rate was determined to be $3.5 \mathrm{~mL} \mathrm{~min}{ }^{-1}$. Under these optimised conditions, the $\mathrm{Mo}\left(\mathrm{NH}_{3}\right)_{2}$ signal was 1100 CPS for a $1 \mathrm{ng} \mathrm{g}^{-1}$ solution, compared to 900 CPS for Mo measured on mass.

Based on the measurement of stable Mo standards, an instrument detection limit of $45.6 \mathrm{pg} \mathrm{g}^{-1}\left(1.6 \mathrm{~Bq} \mathrm{~g}^{-1}\right)$ was calculated based on measurement of $\mathrm{Mo}\left(\mathrm{NH}_{3}\right)_{2}$. The concentrations of $\mathrm{Zr}$ and $\mathrm{Nb}$ were increased and showed $<5$ CPS from $\mathrm{Zr}\left(\mathrm{NH}_{3}\right)_{2}$ or $\mathrm{Mo}\left(\mathrm{NH}_{3}\right)_{2}$ until the concentration exceeded $1 \mathrm{ng} \mathrm{g}^{-1}$. At a concentration of 50 $n g \mathrm{~g}^{-1}$, the signal from $\mathrm{Zr}\left(\mathrm{NH}_{3}\right)_{2}$ and $\mathrm{Mo}\left(\mathrm{NH}_{3}\right)_{2}$ was $160 \mathrm{CPS}$ and 10 CPS, respectively, compared to $4.3 \times 10^{7} \mathrm{CPS}$ from $\mathrm{Mo}\left(\mathrm{NH}_{3}\right)_{2}$ at the same concentration. This shows that ICP-MS/MS can reduce the reliance on relatively time-consuming offline chemical separation prior to measurement. At this stage, the method has only been tested using stable isotopes of Mo, $\mathrm{Zr}$ and $\mathrm{Nb}$, due to the absence of a ${ }^{93} \mathrm{Mo}$ tracer, the production of which is the next stage of this work. As with ${ }^{63} \mathrm{Ni}$, the relatively short half-life of ${ }^{93} \mathrm{Mo}$ for ICP-MS measurement means testing of active ${ }^{93}$ Mo using an Agilent 8900 could offer benefits for low-level measurements. Online separation of Mo from interfering elements also has the potential for stable Mo isotope ratio measurements for applications including past redox conditions in water, ${ }^{51}$ and metabolism pathways relating to biochemistry and environmental chemistry. ${ }^{52}$

\section{Conclusions}

ICP-MS/MS combined with $\mathrm{H}_{2}$ as a collision or reaction gas (either alone or mixed with other gases) has been proven to offer enhanced interference removal for a number of analytes. This study expands the applications of $\mathrm{H}_{2}$ for a number of stable and radioactive pollutants relevant to two groups at the National Physical Laboratory, UK. Stable $\mathrm{Fe}$ and $\mathrm{Ni}$ isotopes are measured as part of a programme of work investigating metal concentrations in air filter samples to meet regulatory requirements. Hydrogen improved polyatomic ${ }^{40} \mathrm{Ar}^{16} \mathrm{O}$ removal for accurate ${ }^{56} \mathrm{Fe}$ measurement, whilst $\mathrm{H}_{2}$ combined with $\mathrm{NH}_{3}$ selectively shifted $\mathrm{Ni}$ to $\mathrm{Ni}\left(\mathrm{NH}_{3}\right)_{3}$, offering removal from isobaric and polyatomic interferences from $\mathrm{Fe}, \mathrm{Cu}$ and $\mathrm{Zn}$, opening the possibility of $\mathrm{Ni}$ isotope ratio measurements for source attribution. The same method was effective for detecting radioactive ${ }^{63} \mathrm{Ni}$ as $\mathrm{Ni}\left(\mathrm{NH}_{3}\right)_{3}$, whilst the reaction with isobaric ${ }^{63} \mathrm{Cu}$ did not proceed. A combination of $\mathrm{H}_{2}$ and $\mathrm{NH}_{3}$ was effective in minimising the background at $m / z=41$, enabling detection of radioactive ${ }^{41} \mathrm{Ca}$ in concrete samples relevant to nuclear decommissioning. Hydrogen was effectively used as the sole gas for measurement of ${ }^{35} \mathrm{Cl}$ as ${ }^{35} \mathrm{Cl}^{1} \mathrm{H}_{2}$, with the results showing the first known ICP-MS/MS measurement of the longlived radionuclide ${ }^{36} \mathrm{Cl}$. The potential of ICP-MS/MS for measurement of ${ }^{93} \mathrm{Mo}$ was also investigated using a stable ${ }^{95} \mathrm{Mo}$ analogue, with selective formation of ${ }^{95} \mathrm{Mo}\left(\mathrm{NH}_{3}\right)_{3}$ achieving good interference removal from stable and radioactive isobars ${ }^{93} \mathrm{Nb}$ and ${ }^{93} \mathrm{Zr}$, respectively. The outcomes of this study show enhanced measurement capability for multiple analytes, and in some cases the possibility of isotope ratio measurement for source attribution, which will have benefits for applications beyond this study.

\section{Conflicts of interest}

There are no conflicts to declare.

\section{Acknowledgements}

The funding of the National Measurement System by the UK's Department for Business, Energy \& Industrial Strategy is gratefully acknowledged. The measurement of ${ }^{41} \mathrm{Ca}$ was supported by the European Metrology Research Program (EMRP) joint research project 'in situ metrology for decommissioning nuclear facilities' (MetroDECOM II). The European Metrology Research Programme (EMRP) is jointly funded by the EMRP participating countries within EURAMET and the European Union. The Nuclear Metrology Group would like to thank the University of Birmingham for collaborating on the ${ }^{63} \mathrm{Ni}$ work through student placements.

\section{References}

1 Reaction data for 70 elements using O2, NH3 and H2 Gases with the Agilent 8800 Triple Quadrupole ICP-MS, https:// www.agilent.com/cs/library/technicaloverviews/public/59914585EN_TechNote8800_ICP-QQQ_reactiondata.pdf, accessed 16/10/21.

2 G. C. Eiden, C. J. Barinaga and D. W. Koppenaal, J. Anal. At. Spectrom., 1996, 11, 317-322.

3 D. W. Koppenaal, G. C. Eiden and C. J. Barinaga, J. Anal. At. Spectrom., 2004, 19, 561-570.

4 S. D. Tanner, J. Anal. At. Spectrom., 1995, 10, 905-921.

5 I. Feldmann, N. Jakubowski and D. Stuewer, Fresenius. J. Anal. Chem., 1999, 365, 422-428.

6 T. Vincent, Thermo Sci. Appl, Note 43442, http:// tools.thermofisher.com/content/sfs/brochures/AN-43442ICP-MS-Selenium-Hydrogen-CRC-AN43442-EN.pdf, accessed 10/08/21.

7 F. Vanhaecke, Agilent Technologies Application Handbook, 2015, vol. 2, pp. 1-92.

8 A. Lee, V. Yang, J. Hsu, E. Wu, R. Shih and K. Mizobuchi, Agilent Application Note, https:/www.agilent.com/cs/library/ applications/5991-1693EN_AppNote_ICP-

MS_8800_semicon_Ca_ultrapure_water.pdf, accessed 10/08/ 21.

9 J. Takahashi, Agilent Application Note, https:// www.agilent.com/cs/library/applications/ appcompendium_icp-qqq-5991-2802en-us-agilent.pdf, accessed 10/08/21.

10 N. Sugiyama, Applications Using the Agilent 8800 and 8900 , 4 th edn, 2020, pp. 27-30.

11 M. Yamanaka, Agil. 8800 ICP-QQQ Appl. Handbook. Prim, 2013, pp. 218-220.

12 S. Manecki, M. lofthouse, P. Boening and S. McSheehy Ducos, Thermo Scientific Application Note, https:// assets.thermofisher.com/TFS-Assets/CMD/ApplicationNotes/AN-43285-ICP-MS-Arsenic-Selenium-Sediment-RockAN43285-EN.pdf, accessed 10/08/21.

13 M. Iglesias, N. Gilon, E. Poussel and J. M. Mermet, J. Anal. At. Spectrom., 2002, 17, 1240-1247. 
14 P. Petrov, B. Russell, N. Douglas and H. Goenaga-infante, Anal. Bioanal. Chem., 2018, 410, 1029-1037.

$15 \mathrm{H}$. Thompkins, B. Russell and S. Goddard, Agilent Application Note, https:/www.agilent.com/cs/library/applications/ application_zr-93_icp-qqq_8800_8900_5994-1532en_usagilent.pdf, accessed 10/08/21.

16 A. Lee, V. Yang, J. Hsu, E. Wu, R. Shih and K. Mizobuchi, Agilent Application Note, https:/www.agilent.com/cs/library/ applications/5991-1693EN_AppNote_ICP-

MS_8800_semicon_Ca_ultrapure_water.pdf, accessed 10/08/21.

17 W. Geiger, Applications Using the Agilent 8800 and 8900, 4th edn, 2020, pp. 37-40.

18 DEFRA, UK Statutory Instrument No. 0000: The Environmental Permitting England and Wales (Amendment) Regulations 2018, National Radiological Protection Board, 2018.

19 S. Goddard, R. J. Brown, D. Butterfield, E. McGhee, C. Robins, A. Brown, S. Beccaceci, A. Lilley, C. Bradshaw and S. Brennan, Annual Report for 2014 on the UK Heavy Metals Monitoring Network, Queen's Printer and Controller of HMSO, 2015.

20 European Commission Council, Directive 2004/107/EC of the European Parliament and of the Council of 15 December 2004 Relating to Arsenic, Cadmium, Mercury, Nickel and Polycyclic Aromatic Hydrocarbons in Ambient Air, 2004.

21 European Parliament, Council of the European Union, Directive 2008/50/EC of the European Parliament and of the Council of 21 May 2008 on Ambient Air Quality and Cleaner Air for Europe, 2008.

22 M. A. Amr, A. F. I. Helal, A. T. Al-Kinani and P. Balakrishnan, J. Environ. Radioact., 2016, 153, 73-87.

23 T. Ohno, Y. Muramatsu, Y. Shikamori, C. Toyama, N. Okabe and H. Matsuzaki, J. Anal. At. Spectrom., 2013, 28, 1283-1287.

24 J. Zheng, K. Tagami, W. Bu, S. Uchida, Y. Watanabe, Y. Kubota, S. Fuma and S. Ihara, Environ. Sci. Technol, 2014, 48(10), 5433-5438.

25 M. Tanimizu, N. Sugiyama, E. Ponzevera and G. Bayon, J. Anal. At. Spectrom., 2013, 28, 1372-1376.

26 Metrology for Radioactive Waste Management, No Title, https:// www.euramet.org/research-innovation/search-researchprojects/details/project/metrology-for-radioactivewastemanagement/?L=0\&tx_eurametctcp_project\% 5 Baction $\% 5 \mathrm{D}=$ show\&tx_eurametctcp_project $\%$ 5 Bcontroller\%

5D=Project\&cHash=31533f8774a0bc6b299635ee4f2519f6, accessed 16/10/2021.

27 B. Russell, H. Mohamud, M. G. Miranda, P. Ivanov, H. Thompkins, J. Scott, P. Keen and S. Goddard, J. Anal. At. Spectrom., 2021, 36, 845-855.

28 K. Nakano, Agilent Application Note, https:// www.agilent.com/cs/library/applications/5991-6852EN.pdf, accessed 10/08/21.

29 J. Nelson, Agilent Application Note, https://www.agilent.com/ cs/library/applications/application_cl-crude-icp-ms-89005994-1094en_us_agilent.pdf, accessed 10/08/21.
30 L. Ashton, P. Warwick and D. Giddings, Analyst, 1999, 124, 627-632.

31 M. Baxter, L. Castle, H. M. Crews, M. Rose, C. Garner, G. Lappin and D. Leong, Food Addit. Contam., Part A, 2009, 26, 139-144.

32 X. Hou, L. F. Østergaard and S. P. Nielsen, Anal. Chem., 2007, 79(8), 3126-3134.

33 X. Hou, Radiochim. Acta, 2005, 93, 611-617.

34 P. E. Warwick, I. W. Croudace and D. J. Hillegonds, Anal. Chem., 2009, 81, 1901-1906.

35 D. Hampe, B. Gleisberg, S. Akhmadaliev, G. Rugel and S. Merchel, J. Radioanal. Nucl. Chem., 2013, 296, 617-624.

36 P. Müller, B. A. Bushaw, K. Blaum, S. Diel, C. Geppert, A. Nähler, N. Trautmann, W. Nörtershäuser and K. Wendt, Fresenius' J. Anal. Chem., 2001, 370, 508-512.

37 S. Merchel, L. Benedetti, D. L. Bourlès, R. Braucher, A. Dewald, T. Faestermann, R. C. Finkel, G. Korschinek, J. Masarik, M. Poutivtsev, P. Rochette, G. Rugel and K. O. Zell, Nucl. Instrum. Methods Phys. Res., Sect. B, 2010, 268, 1179-1184.

38 X. Hou and P. Roos, Anal. Chim. Acta, 2008, 608, 105-139.

39 J. R. De Laeter, K. G. Heumann, R. C. Barber, I. L. Barnes, J. Cesario, T. L. Chang, T. B. Coplen, J. W. Gramlich, H. R. Krouse, I. A. Lebedev, T. J. Murphy, K. J. R. Rosman, M. P. Seyfried, M. Shima, K. Wade, P. De Bievre, R. L. Martin and H. S. Peiser, International Union of Pure and Applied Chemistry, Pure Appl. Chem., 1991, 63(7), 9911002.

40 E. McCurdy and G. Woods, J. Anal. At. Spectrom., 2004, 19, 607-615.

41 M. S. Wheal, E. Decourcy-Ireland, J. R. Bogard, S. H. Thilsted and J. C. R. Stangoulis, Food Chem., 2016, 201, 222-229.

42 L. Poirier, J. Nelson, D. Leong, L. Berhane, P. Hajdu and F. Lopez-Linares, Energy Fuels, 2016, 30(5), 3783-3790.

43 W. Castro, T. Trejos, B. Naes and J. R. Almirall, Anal. Bioanal. Chem., 2008, 392, 663-672.

44 V. Dufailly, L. Noël and T. Guérin, Anal. Chim. Acta, 2006, 565(2), 214-221.

45 S. D. Tanner and V. L. Baranov, J. Am. Soc. Mass Spectrom., 1999, 10, 1083-1094.

46 S. M. Chernonozhkin, S. Goderis, L. Lobo, P. Claeys and F. Vanhaecke, J. Anal. At. Spectrom., 2015, 30, 1518-1530.

47 S. Liu, Y. Li, Y. Ju, J. Liu, J. Liu and Y. Shi, Geochim. Cosmochim. Acta, 2018, 222, 1-16.

48 E. Holm, P. Roos and B. Skwarzec, Int. J. Radiat. Appl. Instrum., Part A, 1992, 43(1-2), 371-376.

49 P. E. Warwick and I. W. Croudace, Anal. Chim. Acta, 2006, 567(2), 277-285.

50 O. Rosskopfová, M. Galamboš and P. Rajec, J. Radioanal. Nucl. Chem., 2011, 289(1), 251-25654.

51 K. Horan, R. G. Hilton, A. J. McCoy-West, D. Selby, E. T. Tipper, S. Hawley and K. W. Burton, Geochemical Perspect. Lett., 2020, 13, 1-6.

52 D. Malinovsky and N. A. Kashulin, Anal. Methods, 2018, 10, 131-137. 